\title{
ANALISIS DAMPAK NILAI TUKAR RUPIAH TERHADAP PEMBIAYAAN OPERASIONAL KAPAL PT. SERASI SHIPPING INDONESIA CABANG MERAK
}

\author{
Dwi Setyoko $^{a}$, Sri Purwantini ${ }^{\text {b }}$ \\ ${ }^{a}$ Taruna Program Studi KALK PIP Semarang \\ ${ }^{\mathrm{b}}$ Dosen Program Studi KALK PIP Semarang
}

\begin{abstract}
ABSTRAK
Nilai tukar mata uang pada suatu negara bersifat fluktuatif dan dinyatakan dalam perbandingan dengan mata uang negara lain. Fluktuasi nilai tukar mata uang memiliki pengaruh terhadap setiap transaksi yang dilakukan oleh perusahaan dalam kegiatan ekspor maupun impor. Fluktuasi kurs memiliki dampak pada perusahaan. Fluktuasi kurs memiliki dampak pada nilai perusahaan karena dapat uang berpengaruh pada jumlah arus masuk kas yang diterima dari kegiatan ekspor perusahaan, juga mempengaruhi jumlah arus keluar kas yang digunakan untuk membayar biaya impor. PT. Serasi Shipping Indonesia adalah perusahan pelayaran yang bergerak di bidang agen pelayaran. Dalam pelaksanaan pelayanan dibutuhkan pembiayaan-pembiayaan operasional kapal yang menggunakan dua mata yaitu rupiah dan US dolar. Sehingga perubahan nilai tukar rupiah sangat berpengaruh terhadap pembiayaan perusahaan, dampak perubahan nilai tukar uang mengakibatkan keuntungan dan kerugian perusahaan. Penelitian ini menggunakan metode kualitatif. Metode pengumpulan data yang digunakan adalah dengan cara observasi, wawancara, studi pustaka, dan studi dokumentasi. Teknik analisis data digunakan antara lain adalah reduksi data, penyajian data dan menarik kesimpulan.
\end{abstract}

\section{Kata Kunci: Dampak, Nilai tukar, Pembiayaan, PT. Serasi Shipping Indonesia.}

\section{PENDAHULUAN}

Nilai tukar mata uang pada suatu negara bersifat fluktuatif dan dinyatakan dalam perbandingan dengan mata uang negara lain. Jika nilai mata uang menguat maka nilai ekspor produk dari negara tersebut akan menjadi lebih tinggi dan sebaliknya jika nilai mata uang melemah, maka nilai impor barang dari negara lain akan lebih rendah atau murah. Fluktuasi nilai tukar mata uang memiliki pengaruh terhadap setiap transaksi yang dilakukan oleh perusahaan dalam kegiatan ekspor maupun impor. Fluktuasi kurs memiliki dampak pada nilai perusahaan karena dapat berpengaruh pada jumlah arus masuk kas yang diterima dari kegiatan ekspor perusahaan atau dari anak perusahaan, juga mempengaruhi jumlah arus keluar kas yang digunakan untuk membayar biaya impor.
Penguatan nilai tukar mata uang tidak selalu memiliki dampak yang positif terhadap perusahaan, sama seperti pelemahan nilai tukar yang belum tentu berdampak negatif pada perusahaan, sebab fluktasi nilai tukar mata uang akan menyebabkan terjadinya tingkat dimana nilai sekarang arus kas perusahaan dipengaruhi fluktuasi kurs dalam perdagangan bebas.

PT. Serasi Shipping Indonesia adalah salah satu perusahaan pelayaran Indonesia yang masih satu grup dengan ASTRA. Tetapi perusahaan ini berkerjasama dengan perusahaan Jardine yang merupakan perusahaan luar negeri. Sehingga untuk kegiatan Shipping lebih banyak campur tangan perusahaan Jardine Shipping Services yang berpusat di Hongkong. PT. Serasi Shipping Indonesia adalah perusahaan pelayaran yang kegiatan bisnisnya di bidang Agency kapal. PT Serasi Shipping Indonesia tidak 
Dwi Setyoko ${ }^{a}$, dan Sri Purwantini ${ }^{\mathrm{b}}$

hanya mengageni kapal milik saja. Akan tetapi juga mengageni kapal-kapal charter. Suatu kapal yang berlabuh di suatu pelabuhan akan membutuhkan pelayanan dan memiliki keperluan yang harus dipenuhi. Dalam semua kegiatan pelayanan tersebut, masing-masing kegiatan membutuhkan biaya dalam pelaksanaannya seperti Clearance in atau Clearance out, Mooring, pembuatan sertifikat kapal, penangan crew on/off.

Pelayanan inspector/superintendent, transportasi, dan lain-lain. Dalam kegiatan pelayanan tersebut biaya-biaya yang diterapkan menggunakan dua mata uang rupiah dan dolar US. Mengingat sebagian besar kapal-kapal yang dilayani PT. Serasi Shipping Indonesia adalah kapal-kapal Asing sehingga pembiayaannya menggunakan dolar US dan rupiah. Sedangkan kas yang diperoleh PT. Serasi Shipping Indonesia adalah dolar US mengingat bahwa PT. Serasi Shipping Indonesia bergabung dengan Jardine Shipping Services. Dengan gejala fluktuasi nilai tukar rupiah memberikan dampak terhadap pembiayaan operasional kapal di PT. Serasi Shipping Indonesia. Tujuan penelitian ini adalah untuk mengetahui dampak nilai tukar rupiah terhadap pembiayaan operasional kapal di PT. Serasi Shipping Indonesia cabang Merak beserta upaya-upaya yang dilakukan untuk meminimalisir kerugian akibat dampak fluktuasi nilai tukar rupiah.

\section{METODE PENELITIAN}

Metode penelitian yang digunakan dalam penelitian ini adalah metode penelitian deskriptif kualitatif. Sehingga dalam penelitian ini meneliti objek-objek dan suatu kondisi dalam suatu permasalahan yang dihadapi PT. Serasi Shipping Indonesia Cabang Merak yang sesuai dengan fokus permasalahan penelitian. Dalam hal ini objek-objek tersebut adalah berupa dokumendokumen, tempat, pelaku dan aktivitasaktivitasnya. Sedangkan kondisi yang dimaksud dalam penelitian ini adalah keadaan yang sedang dihadapi saat itu oleh perusahaan tersebut.

Penelitian ini menggunakan dua sumber data yakni data primer dan data sekunder. Data primer yang digunakan dalam penelitian ini adalah data diperoleh secara langsung dengan melakukan observasi atau mengamati aktivitasaktivitas transaksi pembiayaan dan dampak dari nilai tukar rupiah yang tidak stabil terhadap aktivitas keuangan di PT. Serasi Shipping Indonesia Cabang Merak dan melakukan wawancara dengan beberapa pihak di PT. Serasi Shipping Indonesia. Data sekunder yang digunakan dalam penelitian ini adalah laporanlaporan keuangan serta arsip pelayanan kegiatan kapal selama kapal sandar atau berlabuh di sebuah terminal atau Pelabuhan selama 2 (dua) tahun dari tahun 2014 - 2016.

\section{HASIL DAN PEMBAHASAN}

\section{A. Gambaran Umum Objek Penelitian}

PT. Serasi Shipping Indonesia adalah sebuah perusahaan yang bergerak di bidang logistik pelayaran yang menangani khususnya dalam bidang agen kapal. Peusahaan ini merupakan satu grup dengan Astra Internasional yang merupakan anak perusahaaan dari PT. Serasi Autoraya yang sering disebut dengan SERA. PT. Serasi Auto Raya merupakan anak perusahaan ASTRA Intenasional. Sedangkan PT. ASTRA Internasional mayoritas kepemilikan sahamnya dikuasai oleh Jardine.

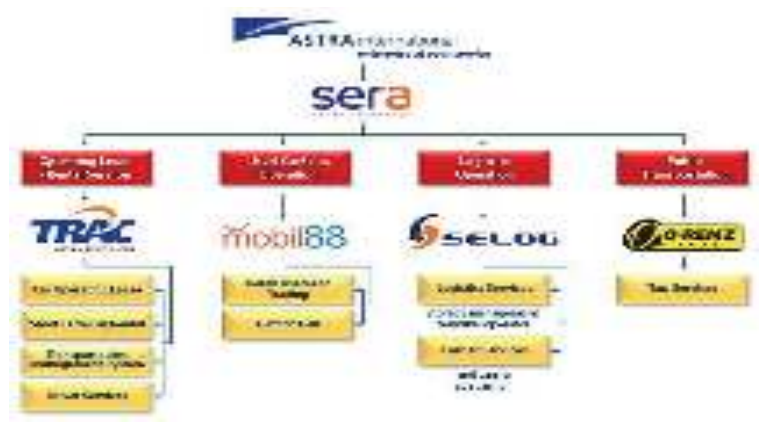

Gambar 1. Bagan ASTRA International Grup 
Dilihat dari bagan di atas bahwa posisi PT. Serasi Shipping Indonesia adalah di bagian logistik servis yang mana merupakan group Serasi Logistik atau disebut sebagai SELOG dan merupakan anak perusahaan dari Serasi Autoraya. PT. Serasi Shipping Indonesia hampir keseluruhan saham dimiliki oleh Jardine sehingga kadang orang menyebutnya PT. Jardine Shipping Services. Sehingga menimbulkan pengoperasian dan manajemen perusahaan tersebut dikontrol oleh Perusahaan Jardine yang berpusat di Hongkong. PT. Serasi Shipping Indonesia sendiri mempunyai cabang di seluruh Indonesia dan sedangkan untuk yang di luar negeri di bawah Jardine Shipping Services.

Perusahan ini bergerak di bidang logistik pelayaran yang khususnya menangani keagenan kapal. Keagenan kapal itu sendiri adalah pelayanan kegiatan kapal selama kapal itu sandar atau berlabuh di sebuah terminal atau pelabuhan meliputi kegiatan pelayanan pengurusan dokumendokumen kapal, perizinan, penanganan dan pelayanan $\mathrm{ABK}$ dan pihak-pihak lain yang berkaitan dengan kebutuhan kapal seperti inspector, superintendet, dan teknisi kapal. Adapun kapal-kapal yang diageni oleh PT. Serasi Shipping Indonesia Cabang Merak adalah milik sendiri dan kapal-kapal charter atau sewa yang merupakan penunjukan dari pemilik perusahaan kapal tersebut atau sering disebut owner. Mayoritas kapal yang diageni di PT. Serasi Shipping Indonesia adalah kapal-kapal charter atau sewa yang berbendera asing.

Dan adapun jenis-jenis kapal yang dilayani PT. Serasi Shipping Indonesia Cabang Merak adalah sebagai berikut:

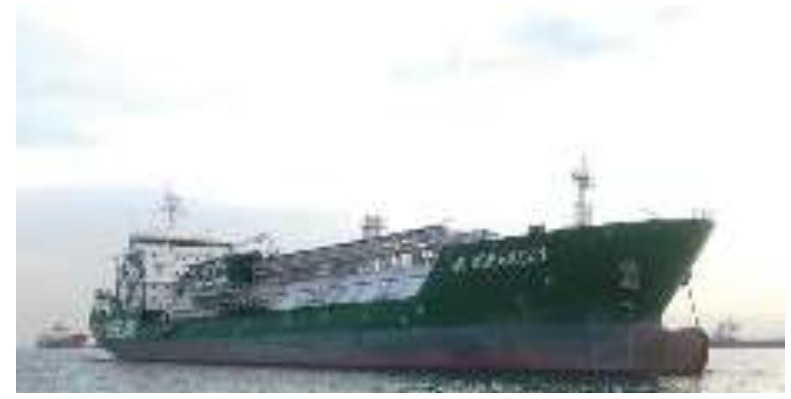

Gambar 2. LEG JS Greensky merupakan salah satu kapal gas yang dilayani PT. Serasi Shipping Indonesia Cabang Merak

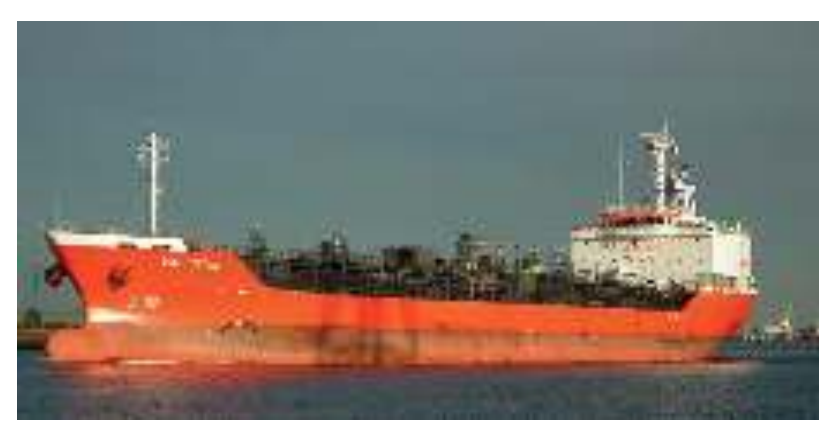

Gambar 3. MT. Valentine salah satu kapal tanker yang dilayani PT. Serasi Shipping Indonesia Cabang Merak

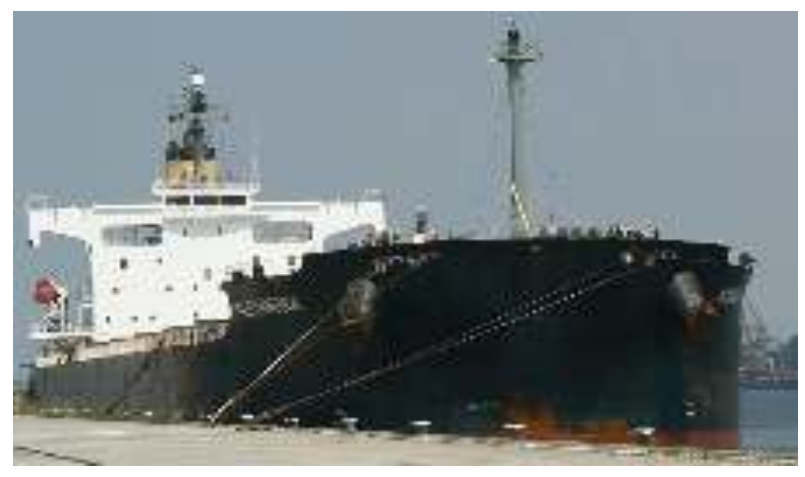

Gambar 4. MV. Alexandra satu kapal general cargo yang dilayani PT. Serasi Shipping Indonesia Cabang Merak

\section{B. Analisis hasil penelitian}

1. Dampak Nilai Tukar Rupiah Terhadap Pembiayaan Operasional Kapal di PT. Serasi Shipping Indonesia Cabang Merak. Peristiwa tidak stabilnya nilai tukar mata uang terjadi 2 (dua) tahun terakhir ini. Hal ini juga di alami oleh Indonesia yang mengalami depresiasi mata rupiah terhadap dolar. Hal tersebut disebabkan karena dari faktor internal (domestik) maupun eksternal (luar negeri), penyebab terpuruknya rupiah tercermin dari fundamental ekonomi negara, artinya jika fundamental ekonomi suatu negara melambat maka akan berdampak pada rupiah terdepresiasi. Ketidakstabilan ekonomi juga dipengaruhi oleh faktor eksternal, yakni adanya sentimen dari The Fed dimana pasar internasional melihat adanya kenaikan suku bunga, sehingga pasar sudah ancang-ancang memegang dolar, kemudian melemahnya rupiah juga dipicu dengan sebagian besar kinerja perusahaan di bawah ekspektasi. Hal ini 
membuat investor beralih ke emerging market lain. Fluktuasi nilai tukar rupiah tersebut berpengaruh terhadap perusahaanperusahaan yang ada di Indonesia salah satunya PT. Serasi Shipping Indonesia. Hal tersebut dapat dilihat pada grafik di bawah ini selama 10 (sepuluh) bulan yakni pada bulan Agustus 2014 s.d. Agustus 2015 selama peneliti melakukan penelitian di PT. Serasi Shipping Indonesia Cabang Merak.

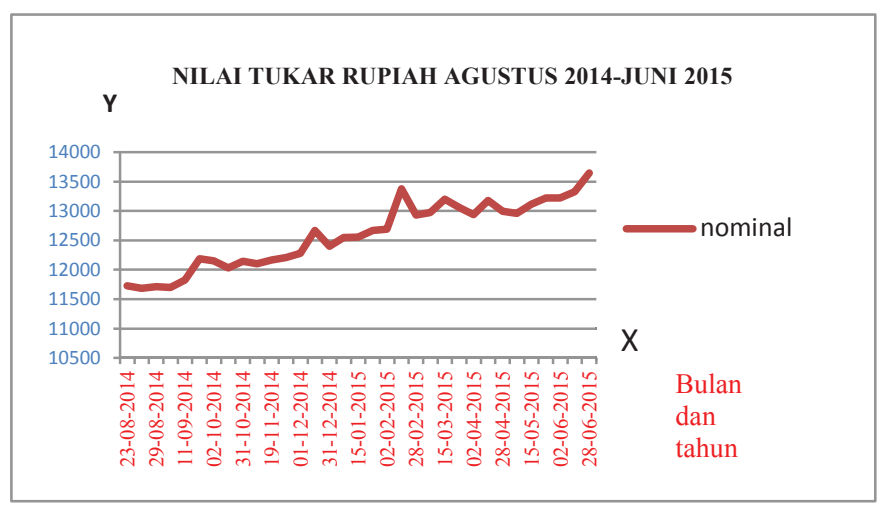

Gambar 5. Nilai tukar rupiah terhadap dolar bulan Agustus 2014 sampai Juni 2015

Keterangan:

$\mathrm{X}=$ Menunjukan bulan dan tahun penelitian

$\mathrm{Y}=$ Menunjukan nilai nominal rupiah terhadap dolar

Dilihat dari grafik di atas dolar mengalami kenaikan terhadap rupiah, akan tetapi kenaikan kenaikan tersebut tidaklah stabil terlihat jelas pada bulan Februari, Maret, dan April 2015. Hal tersebut mempunyai dampak positif maupun negatif bagi perusahaan perusahaan di Indonesia termasuk PT. Serasi Shipping Indonesia Cabang Merak. Adapun dampak tersebut dibagi menjadi 2 (dua) yaitu:

a. Dampak Positif

Dampak positif dalam hal ini membuat perusahaan lebih kearah keuntungan dan kemajuan, dampak positif yang dimaksudkan adalah Perusahaan mengalami peningkatan keuntungan, peningkatan terjadi ketika nilai tukar rupiah melemah atau mengalami penurunan. Karena penerimaan yang berupa US dolar dan pembiayaan menggunakan rupiah dan US dolar. Kemudian dampak positif yang lain adalah market mengalami peningkatan, hal ini disebabkan karena pembiayaan yang mengalami penurunan yang diakibatkan oleh melemahnya rupiah, sehingga market mengalami peningkatan.

b. Dampak Negatif

Dampak Negatif yang dialami Perusahaan adalah Perusahaan mengalami penurunan kerugian, kerugian terjadi ketika nilai tukar rupiah mengalami penguatan dan US dolar melemah, disebabkan karena penerimaan yang berupa US dolar dan pembiayaan menggunakan mata uang rupiah dan US dolar. Dampak negatif yang lain adalah Market lesu, kelesuan ini diakibatkan oleh pembiayaan yang meningkat sehingga membuat market mengalami lesu. Kemudian Perusahaan mengalami kesulitan untuk memprediksi keuntungan. Tidak stabilnya nilai tukar rupiah membuat perusahaan mengalami kesulitan dalam menentukan sebuah kebijakan khususnya kebijakan keuangan.

Dampak tersebut tersebut di pengaruhi oleh faktor-faktor di bawah ini:

a. Nilai tukar rupiah yang tidak stabil

b. Sebagian besar kapal yang dilayani merupakan kapal asing

c. Pembiayaan yang menggunakan dua mata uang yaitu rupiah dan US dolar.

\section{Pembahasan masalah}

Adapun Faktor-faktor yang mempengaruh Nilai Tukar Rupiah Terhadap Pembiayaan Operasional Kapal di PT. Serasi Shipping Indonesia Cabang Merak, yaitu:

a. Nilai tukar rupiah yang tidak stabil

Nilai tukar rupiah yang tidak stabil merupakan faktor utama mempengaruhi pembiayaan operasional kapal di PT. Serasi Shipping Indonesia Cabang Merak. Karena semua pembiayaan 
operasional kapal menggunakan uang. Dalam penggunaan uang tersebut perusahaan menggunakan dua mata uang yaitu rupiah dan US dolar yang berpengaruh terhadap perubahan nilai tukar rupiah yang tidak stabil. Hal tersebut karena adanya proses pertukaran mata uang ketika dalam proses pendapatan pelayanan dan pembiayaan opersional kapal sehingga penentuan nilai mata uang sangat berpengaruh terhadap pembiayaan tersebut.

b. Sebagian besar kapal yang dilayani merupakan kapal asing

Kapal-kapal yang dilayani oleh PT. Serasi Shipping Indonesia merupakan kapal-kapal asing, sehingga berhubungan dengan pendapatan yang diperoleh berupa pembayaran pelayanan yang menggunakan mata uang US dolar dan pembiayayaannya menggunakan rupiah dan US dolar.

c. Pembiayaan yang menggunakan dua mata uang yaitu rupiah dan US dolar.

Pembiayaan menggunakan dua mata uang membuat terjadinya pertukaran nilai mata uang tersebut. Hal tersebut terjadi ketika perusahaan dalam penerimaan menggunakan mata uang US dolar sedangkan pengeluarannya menggunakan rupiah dan US dolar. Hal tersebut tidak akan terjadi apabila penerimaan dan pengeluaran menggunakan mata uang yang sama, sehingga tidak terjadinya pertukaran mata uang.

- Dampak positif dari fluktuasi nilai tukar rupiah terhadap pembiayaan operasional kapal PT. Serasi Shipping Indonesia Cabang Merak.

a. Mengalami peningkatan keuntungan

Dampak positifnya adalah perusahaan mengalami peningkatan keuntungan, hal ini dikarenakan PT. Serasi Shipping Indonesia Cabang Merak merupakan salah satu perusahaan Internasional maka pendapatan yang diperoleh berupa kurs mata uang asing yaitu US Dolar. Sebagian besar kapal yang dilayani PT. Serasi Shipping Indonesia Cabang Merak merupakan kapal berbendera asing atau kapal yang berasal dari luar negeri.

Untuk pembiayaan operasional pelayanan kapal yang PT. Serasi Shipping Indonesia Cabang Merak sebagian besar menggunakan mata uang rupiah, sehingga menambah keuntungan perusahaan. Ketika kurs mata uang rupiah pada saat itu mengalami penurunan sedangkan US Dolar mengalami penguatan, hal itu berdampak pada keuntungan didapat dari selisih penerimaan yang menggunakan US dolar dan pengeluaran sebagian besar menggunakan mata uang rupiah. Maka diperoleh keuntungan yang meningkat ketika kurs rupiah mengalami penurunan. Hal tersebut bisa diberikan contoh seperti pembayaran mooring/unmooring sebesar Rp. 950.000,- dan dianggaran adalah $\$ 100$ maka perusahaan mendapat keuntungan yang cukup banyak ketika nilai mata uang rupiah melemah. Tidak hanya itu saja tetapi perubahan nilai tukar berpengaruh terhadap kedatangan kapal yang dilayani PT. Serasi Shipping Indonesia Cabang Merak.

b. Market mengalami peningkatan

Dampak positif lain adalah market mengalami peningkatan, peningkatan ini disebabkan oleh menurunnya rupiah dan meningkatnya atau menguatnya dolar. Hal tersebut terjadi karena kegiatan ekspor barang meningkat, kerena banyak produsen yang lebih banyak mengekspor barangnya dikarenakan harga di luar negeri lebih mahal dibandingkan di dalam negeri. Sehingga keuntungan yang diperoleh produsen tersebut meningkat, dan menyebabkan arus barang di pelabuhan meningkat. Keuntungan tersebut disebabkan 
juga karena penerapan harga pada pelayanan perusahaan yang relatif murah sehingga menarik banyak konsumen memilihnya. Market yang dibahas disini adalah para owner-owner kapal atau para pemilik kapal serta para pemilik barang yang akan atau sudah mengapalkan barang-barangnya.

Market sendiri ditentukan oleh banyaknya jumlah kedatangan kapal yang dilayani, baik itu kapal milik maupun kapal charter maupun kapal penunjukkan oleh owner kapal atau pemilik kapal. Peningkatan market tersebut bisa dibuktikan dan dilihat pada grafik kedatangan kapal perbulannya di bawah ini.

Gambar 6. Jumlah kedatangan kapal berdasarkan kurs dollar

Agustus 2014 sampai Juni 2015

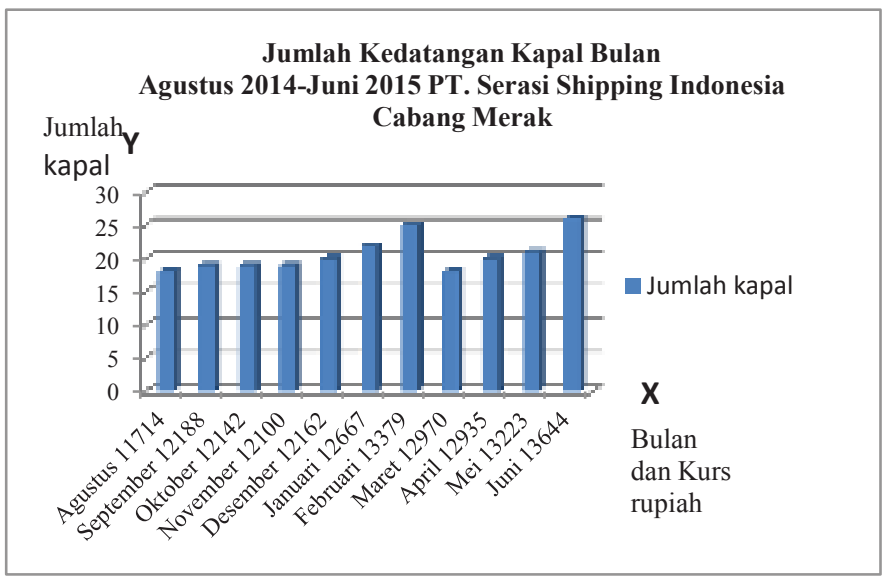

Keterangan:

$\mathrm{X}$ : Bulan dan jumlah rata-rata kurs perbulan tersebut

Y: Jumlah kapal yang dilayani perusahaan.

Dilihat dari grafik di atas diketahui bahwa semakin menguat dolar dan melemahnya rupiah berdampak pada ramainya aktivitas kedatangan kapal. Sehingga berdampak pada market yang meningkat. Seperti contoh pada bulan Februari 2015 market mengalami peningkatan yang disebabkan oleh rupiah yang melemah dan menguatnya dolar.
Peningkatan market atau pangsa pasar tidak hanya dipengaruhi karena faktor kapal asing yang dilayani PT Serasi Shipping Indonesia, tetapi kapal-kapal dalam negeri ikut serta dalam mengisi market atau pangsa pasar jasa yang ditawarkan PT. Serasi Shipping Indonesia Cabang Merak. Peningkatan market atau pasar ini juga berpengaruh terhadap peningkatan keutungan serta kemajuan perusahaan.

- Dampak negatif fluktuasi nilai tukar rupiah terhadap pembiayaan operasio-nal kapal PT. Serasi Shipping Indonesia Cabang Merak.

a. Perusahaan Mengalami kerugian

Dampak negatifnya adalah Perusahaan mengalami kerugian, Perusahaan ketika rupiah menguat dan dolar mengalami penurunan. Hal tersebut terjadi dikarenakan pemasukan yang diperoleh perusahaan berupa mata uang dolar sedangkan pengeluaran atau pembiayaan sebagian besar menggunakan mata uang rupiah.

Sehingga perusahaan mengalami penurunan keuntungan, yang disebabkan karena pembiayaan sebagian besar menggunakan mata uang rupiah. Hal ini menyebabkan ketika mata uang rupiah mengalami penguatan dan dolar melemah mengakibatkan kerugian penerimaan atau dalam hal ini pengurangan keuntungan yang didapat. Hal tersebut dipengaruhi juga karena faktor sebagian besar kapal yang dilayani merupakan kapal berbendera asing atau kapal-kapal asing.

Salah satu dampak negatif dapat diilustrasikan yaitu pembiayaan dalam kegiatan mooring/unmooring ditetapkan dianggarkan \$100 dan beban yang harus dibayarkan dalam rupiah Rp. 950.000,-Kalau rupiah terhadap dolar dalam keadaan \$1 (satu US dolar) = Rp. 13.100, maka keuntungan yang didapatkan relatif banyak yaitu Rp. 360.000,dibandingkan ketika \$1 (satu US dolar) $=$ Rp. 11.714,- , maka keuntungan yang didapatkan relatif sedikit dibandingkan 
dengan pada waktu dolar dalam posisi Rp. 13.100,-, keuntungan yang didapat yaitu Rp. 221.400,-. Apalagi seandainya nilai rupiah terhadap dolar mencapai angka Rp. 9.000 hal tersebut akan berdampak pada kerugian bagi perusahaan, karena perusahaan akan mendapat kerugian Rp. 50.000,-. Dari uraian tersebut bahwa nilai tukar rupiah berpengaruh terhadap keuntungan ataupun kerugian pada PT. Serasi Shipping Indonesia Cabang Merak.

\section{b. Market lesu}

Market adalah ujung tombak dari bisnis. Maju mundurnya sebuah perusahaan dipengaruhi oleh market sebuah perusahaan itu sendiri, akibat dari fluktuasi nilai tukar rupiah menyebabkan market sepi, hal ini merupakan dampak yang ditimbulkan oleh nilai tukar rupiah yang tidak stabil, tetapi kejadian ini berbeda dari sebagian besar perusahaanperusahaan di Indonesia. Ketika mata uang rupiah menguat dan nilai tukar mata uang dolar mengalami penurunan. Hal ini membuat pasar ekspor lesu dan aktivitas di pelabuhan pun menjadi lesu. Membuat jumlah kedatangan kapal yang dilayani, membuat penerimaan yang menurun, dan juga membuat para konsumen yakni para pemilik kapal atau yang sering disebut owner kapal yang mengeluhkan hal tersebut karena peningkatan biaya yang harus dibayarkan ketika kapal miliknya sandar di pelabuhan-pelabuhan di Indonesia. Kejadian tersebut dapat dilihat pada grafik di bawah ini:

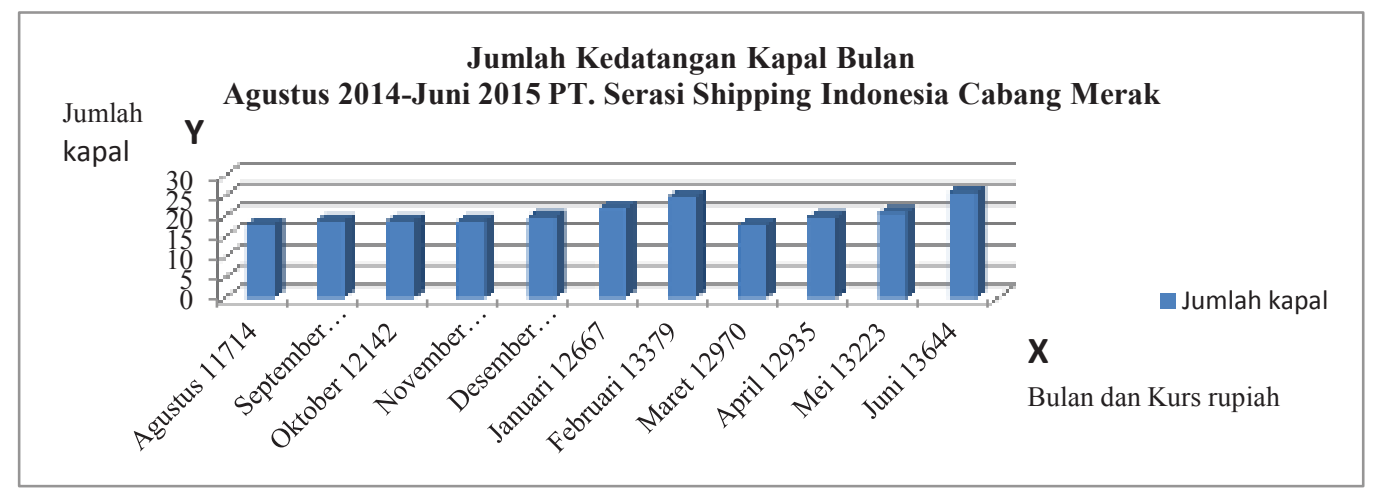

Gambar 7. Jumlah kedatangan kapal berdasarkan kurs dolar Agustus 2014 sampai Juni 2015

Keterangan:

$\mathrm{X}$ : Bulan dan jumlah rata-rata kurs perbulan tersebut

Y: Jumlah kapal yang dilayani perusahaan.

Berdasarkan grafik di atas bisa dilihat bahwa terjadi penurunan jumlah kedatangan kapal yang dilayani PT. Serasi Shipping Indonesia Cabang Merak ketika nilai tukar dolar mengalami penurunan dan nilai mata uang rupiah menguat. Dapat dilihat pada bulan Februari 2015 ke bulan Maret 2015, dari jumlah kapal 25 ketika nilai rupiah Rp.13.379,- menjadi ke 18 kapal yang dilayani pada posisi Rp.12.970,-. Hal tersebut membuktikan bahwa perubahan nilai tukar rupiah berpengaruh terhadap market atau pangsa pasar di PT. Serasi Shipping Indonesia Cabang Merak.

c. Kesulitan untuk memprediksi keuntungan dalam rangka menentukan kebijakan keuangan

Fluktuasi atau tidak stabilnya nilai tukar rupiah terhadap dolar barakibat pada perusahaan mengalami kesulitan dalam memprediksi keuntungan perusahaanya, membuat sulit bagi perusahaan perusahaan untuk menentukan arah kebijakan khususnya kebijakan dalam bidang keuangan. Mengingat nilai tukar yang rupiah yang terus berubah-ubah tiap harinya. 
Dwi Setyoko ${ }^{\mathrm{a}}$, dan Sri Purwantini ${ }^{\mathrm{b}}$

Membuat para pengusaha harus pandai memprediksinya agar bisnisnya tidak mengalami kerugian. Hal ini juga yang dialami juga oleh PT.Serasi Shipping Indonesia Cabang Merak. Karena PT. Serasi Shipping Indonesia Cabang Merak merupakan perusahaan bertaraf Internasional maka tidak akan lepas dari pembiayaan perusahaan yang menggunakan mata uang asing atau lebih jelasnya adalah US dolar. Pengaruh fluktuasi nilai tukar mata uang baik US dolar maupun rupiah mengakibatkan perusahaaan sulit dalam mengambil kebijakan khususnya dalam kebijakan keuangan perusahan agar tidak mengalami penurunan keuntungan akibat dari dampak tidak stabilnya nilai tukar rupiah.

- Upaya-upaya yang dilakukan untuk meminimalisir kerugian akibat dampak fluktuasi rupiah.

a. Pada segi keuangan

1) Menaikkan tarif pelayanan

Dalam hal ini menaikkan tarif pelayanan merupakan strategi bisa diambil untuk meminimalisir penurunan keuntungan pada PT. Serasi Shipping Indonesia Cabang Merak. Tetapi dalam menentukan kebijakan tarif pelayanan harus mempertimbangkannya sehingga tidak timbul dampak pada perusahaan akan kehilangan konsumennya. Sehingga dalam menaikan tarif haruslah mempertimbangkan persaingan dari perusahaan kompetitornya dengan menaikkan harga tidak terlalu tinggi dan tidaklah mengambil keuntungan sebesar-besarnya. Karena apabila itu terjadi maka konsumen akan meninggalkan perusahaan dan beralih kepada perusahaan kompetitor.

2) Memanfaatkan keuntungan dari market lokal
Dari segi keuangan adalah memanfaatkan keuntungan dari market lokal yang dalam hal ini merupakan market dalam negeri. Yaitu keuntungan yang diperoleh pada market lokal digunakan untuk menutupi kerugian yang didapat dari market asing yang digunakan untuk mencegah penurunan keuntungan perusahaan. Karena market lokal tidak terpengaruh oleh peruahan nilai tukar rupiah yang tidak stabil, karena market lokal hanya menggunakan satu mata uang saja dalam transaksinya, baik itu dalam segi penerimaan maupun pembiayaan yaitu menggunakan mata uang rupiah. Hal ini digunakan untuk mendukung kenaikan harga pelayanan yang tidak terlalu besar, tetapi tetap menghasilkan keuntungan yang kurang lebih sama tanpa ada penurunan.

3) Menyimpan keuntungan untuk cadangan

Menyimpan keuntungan untuk cadangan. Yang dimaksudkan dalam hal ini adalah menyimpan keuntungan yang berlebih yang diperoleh ketika nilai tukar rupiah melemah. Kemudian digunakan sebagai cadangan ketika nilai tukar rupiah menguat sehingga didapatkan pendapatan yang stabil per bulanya.

\section{b. Pada segi market}

Dari segi pasar sendiri perusahaan menggunakan pasar lokal ketika nilai tukar rupiah menguat, digunakan untuk menutupi kerugian atau penurunan keuntungan ketika market asing tidak bisa diandalkan. Sehingga perusahaan mencari pasar-pasar lokal untuk mendapatkan keuntungan. Seperti contoh dengan menguasai pasar-pasar dalam negeri. Dengan cara mendekati produsen-produsen penghasil barang yang berada di Indonesia agar memakai jasa dari PT. Serasi Shipping Indonesia. Karena di Indonesia sendiri PT. Serasi Shipping Indonesia tidak bisa mendekati 
para pemilik kapal, karena mayoritas pemilik kapal lokal telah memiliki keagenan kapalnya sendiri di seluruh Indonesia. Hal tersebut dilakukan karena pasar lokal tidak terpengaruh oleh perubahan nilai tukar rupiah yang tidak stabil. Karena pasar lokal hanya menggunakan 1 (satu) mata uang saja yaitu rupiah. Sehingga tidak terjadi pertukaran mata uang yang berpengaruh terhadap nilai mata uang tersebut.

\section{KESIMPULAN}

Dari uraian dan bahasan yang telah diuraikan di atas maka dapat ditarik kesimpulan bahwa faktor-faktor yang menyebabkan pembiayaan perusahaan yang terpengaruh oleh perubahan nilai tukar uang rupiah terdapat tiga faktor yaitu nilai tukar rupiah yang tidak stabil, mayoritas kapal yang dilayani merupakan kapal asing, pembiayaan yang menggunakan dua mata uang yaitu rupiah dan US dolar.

Terdapat 2 (dua) dampak yang ditimbulkan akibat fluktuasi rupiah, yaitu:

\section{a. Dampak Positif}

Dampak positif dalam hal ini membuat perusahaan mengalami peningkatan keuntungan dan kemajuan, dampak positif|, peningkatan ini terjadi ketika nilai tukar rupiah melemah atau mengalami penurunan. Karena penerimaan yang berupa US dolar dan pembiayaan menggunakan rupiah dan US dolar. Kemudian market mengalami peningkatan, peningkatan ini terjadi karena pembiayaan yang mengalami penurunan yang diakibatkan oleh melemahnya rupiah, sehingga market mengalami peningkatan.

b. Dampak Negatif

Dampak positif dalam hal ini perusahaan mengalami kerugian, kerugian ini terjadi ketika nilai tukar rupiah mengalami penguatan dan US dolar melemah, disebabkan karena penerimaan yang berupa US dolar dan pembiayaan menggunakan mata uang rupiah dan US dolar. Kemudian dampak yang kedua adalah market lesu, kelesuan ini diakibatkan oleh pembiayaan yang meningkat sehingga membuat market mengalami lesu. Kemudian dampak yang ketiga adalah Perusahaan mengalami kesulitan untuk memprediksi keuntungan dalam rangka untuk memprediksi keuntungan. Tidak stabilnya nilai tukar rupiah membuat perusahaan mengalami kesulitan dalam menentukan sebuah kebijakan khususnya kebijakan keuangan.

Penyelesaian masalah yang diterapkan oleh perusahaan dalam mengatasi dampak perubahan nilai tukar rupiah terhadap pembiayaan perusahaan adalah perusahaan menaikkan layanan, memanfaatkan keuntungan dari market lokal, menyimpan keuntungan untuk cadangan keuangan perusahaan dan memperluas market lokal.

\section{DAFTAR PUSTAKA}

Martopo, Arso. Manajemen Armada Kapal Dalam Bisnis Pelayaran. Semarang: Politeknik Ilmu Pelayaran Semarang

Moleong, Lexy J. 2015. Metode Penelitian Kualitatif. Bandung: PT Remaja Rosdakarya

Natsir, M. 2014. Ekonomi Moneter dan Kebanksentralan. Jakarta: Mitra Wacana Media

Prastowo, Andi. 2012. Metode Penelitian Kualitatif Dalam Prespektif Rancangan Penelitian. Yogyakarta: AR-Ruzz Media

Sugiyono. 2015. Metode Penelitian Pendidikan Pendekatan Kuantitatif, Kualitatif, dan $R \& D$. Bandung: Alfabeta

Widoyoko, Eko P. 2012. Teknik Penyusunan Instrumen Penelitian. Yogyakarta: Pustaka Pelajar 


\title{
ANALISIS KURANG OPTIMALNYA PELAYANAN PENGOPERASIAN KEAGENAN KAPAL ASING GUNA TERCIPTANYA KELANCARAN PELAYANAN DI PELABUHAN GRESIK
}

\author{
Arif Sudarmanto $^{\mathrm{a}}$, Sri Purwantini ${ }^{\mathrm{b}}$ \\ ${ }^{a}$ Taruna Program Studi KALK PIP Semarang \\ ${ }^{b}$ Dosen Program Studi KALK PIP Semarang
}

\begin{abstract}
ABSTRAK
Dalam melaksanakan pelayanan pengoperasian keagenan kapal asing pihak keagenan akan berinteraksi dengan berbagai instansi dalam perizinan dan pengurusan dokumen kapal asing. Seperti Imigrasi, Karantina, Syahbandar, Pelindo, dan Bea Cukai. Adanya faktor penghambat pada pelayanan pengoperasian keagenan kapal asing di Gresik dapat mempengaruhi kinerja keagenan menjadi kurang optimal, karena hal tersebut maka perlu adanya upaya dalam meningkatkan pelayanan pengoperasian keagenan kapal asing di Gresik.

Penelitian ini menggunakan metode penelitian deskriptif kualitatif. Dari hasil penelitian dapat diketahui faktor penghambat pelayanan pengoperasian keagenan kapal asing di Gresik antara lain kurangnya fasilitas kapal tunda yang ada di Pelabuhan Gresik sehingga olah gerak kapal menjadi terkendala, dan proses pengurusan dokumen di Bea Cukai Gresik yang belum menerapkan sistem online 24 (dua puluh empat) jam. Berdasarkan hasil penelitian di atas upaya yang dilakukan oleh Pelindo Gresik dalam mengatasi fasilitas kapal tunda yang terbatas adalah mendatangkan tambahan kapal tunda yang diperbantukan oleh Pelabuhan Tanjung Perak Surabaya sehingga waktu tunggu kapal tunda menjadi lebih cepat, dan upaya yang dilakukan Bea Cukai Gresik yaitu pengurusan dokumen di luar jam kerja dapat dilakukan dengan melakukan konfirmasi waktu pengurusan terlebih dahulu sehingga aktivitas pelayanan kapal asing dapat dilakukan, dengan demikian pengoperasian keagenan kapal asing di Gresik dapat menjadi lebih optimal dan efisien.
\end{abstract}

Kata kunci: Pelayanan pengoperasian keagenan, kapal asing, faktor penghambat

\section{PENDAHULUAN}

Dewasa ini, peran kapal laut sebagai alat transportasi sangat besar. Meskipun terdapat angkutan udara dan darat, angkutan laut melalui kapal dinilai lebih efektif dan efisien untuk pengiriman dengan jumlah besar. Kapasitas muatan yang cukup besar dengan biaya terjangkau menjadi pertimbangan penggunaan kapal laut sebagai alternatif pengiriman barang bagi para importir maupun eksportir.

Indonesia memiliki banyak pelabuhan, salah satunya di daerah Gresik. Kegiatan ekspor dan impor menyebabkan banyak kapal asing berlabuh di wilayah Indonesia. Perizinan untuk kapal kapal asing berbeda dengan perizinan kapal domestik sehingga peran agen dalam menerima, memberikan pelayanan dan informasi sangat penting.

Dalam melaksanakan pelayanan kapal asing keagenan harus berinteraksi dengan berbagai instansi dalam perizinan kapal asing. Kurangnya informasi akan mengakibatkan hambatan di instansi maupun di lapangan. Dalam menunjang kegiatan keagenan di daerah pelabuhan, pada umumnya melibatkan instansi yaitu Kantor Syahbandar setempat. Kantor Bea dan Cukai setempat, Kantor Karantina setempat, Kantor Pelindo setempat, Kantor Imigrasi setempat, Kantor Pelabuhan Khusus (PELSUS).

Semakin maju dan berkembangnya dunia usaha serta meningkatnya arus barang dan kapal asing maupun domestik yang masuk daerah pelabuhan begitu besar, maka pelayanan pengoperasian keagenan pada perusahaan yang menangani kapal khususnya kapal asing harus melakukan pelayanan yang maksimal, akan tetapi berdasarkan pengamatan di lapangan terdapat hambatan dalam pelayanan pengoperasian keagenan kapal asing di Gresik yaitu terbatasnya 
fasilitas pelayanan kapal tunda di Pelindo III dan belum diterapkannya sistem online di Bea Cukai sehingga membutuhkan birokrasi yang panjang. Karena dalam bisnis pelayaran diperlukan pelayanan yang cepat dan tepat sehingga pelayanan terhadap kapal asing dapat berjalan dengan lancar dan maksimal.

Tujuan penelitian ini untuk mengetahui faktor-faktor penghambat pelayanan pengoperasian keagenan di Pelabuhan Gresik.

\section{METODE PENELITIAN}

Ditinjau dari jenis datanya pendekatan penelitian yang digunakan dalam penelitian ini adalah penelitian deskriptif kualitatif. Pengumpulan data dilakukan dengan observasi, wawancara, dan studi dokumentasi. Teknik wawancara yang digunakan dalam penelitian ini adalah wawancara terbuka, data wawancara diperoleh dengan bertanya langsung kepada narasumber yang dipilih yaitu pihak-pihak yang berkompeten yang dianggap mampu memberikan gambaran dan informasi yang digunakan untuk menjawab permasalahan yang ada dalam penelitian ini. Data wawancara diperoleh dengan melakukan wawancara dengan narasumber guna mendapatkan informasi, Narasumber tersebut adalah Staf Lapangan Pelindo III Gresik, Seksi Administrasi manifest Bea Cukai, Staf operasional PT. Bintang Samudra Utama Gresik, Staf operasional PT. Bahtera Adhiguna Gresik, Staf Operasional PT. Varia Usaha Lintas Segara Gresik. Dalam melakukan pengamatan, penulis menjadi partisipan dimana terlibat langsung dalam kegiatan pelayanan kepada kapal-kapal asing.

\section{HASIL PENELITIAN DAN PEMBAHASAN}

Terdapat tahapan pengurusan kapal asing atau tahapan yang harus dilalui oleh pengguna jasa atau keagenan, yaitu:

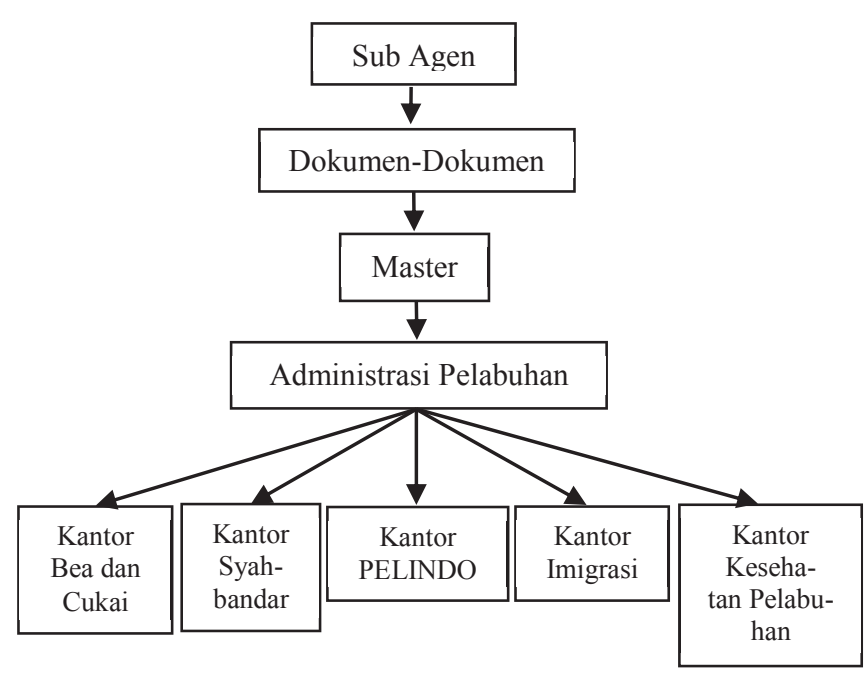

Gambar 1. Alur pengurusan kapal asing di Pelabuhan

Dari diagram di atas dapat dijelaskan bahwa alur pengurusan kapal asing yang tiba di pelabuhan dimulai dari pihak keagenan kapal asing, keagenan yang telah ditunjuk akan menaiki kapal (on board) untuk mengambil dokumen dari kapal tentunya melalui persetujuan dari Nahkoda (master) untuk proses clearance in, selanjutnya pihak keagenan melakukan proses administrasi pelabuhan dengan mengurus dokumen di berbagai instansi terkait, yaitu dengan Instansi Bea Cukai, Syahbandar, Pelindo, Imigrasi, dan Karantina.

Selama melaksanakan penelitian penulis memperoleh data-data, dan hasil penelitian dari wawancara dengan narasumber terkait mengenai pelayanan pengoperasian keagenan kapal asing di Gresik. Hasil pengamatan memberikan gambaran tentang pelayanan pengoperasian keagenan kapal asing di Gresik dimana masih terdapat pelayanan yang belum optimal dan timbul permasalahan yang mengakibatkan belum optimal pengoperasian keagenan kapal asing di Gresik. Permasalahan pelayanan tersebut disebabkan karena terbatasnya fasilitas pelayanan kapal tunda di pelabuhan Gresik yang kurang memadai, dalam hal ini timbul kendala yaitu tertundanya pelayanan olah gerak kapal baik pelayanan kapal sandar dan lepas, dengan demikian maka kapal tidak dapat melakukan sandar atau lepas sesuai dengan rencana jadwal yang telah ditetapkan atau estimasi waktu yang telah ditetapkan. 
Arif Sudarmanto dan Sri Purwantini ${ }^{\mathrm{b}}$

Kemudian faktor kedua disebabkan karena sistem pengurusan clearance dokumen di Instansi Bea Cukai yang belum menerapkan sistem online 24 (dua puluh empat) jam, sehingga banyaknya birokrasi pengurusan kapal asing yang dilakukan membutuhkan waktu lama.

Dari hasil observasi, wawancara, serta dokumentasi ditemukan adanya kendalakendala yang dihadapi dalam pelayanan pengoperasian keagenan kapal tentunya ini akan sangat berpengaruh terhadap kinerja keagenan sehingga mengakibatkan terhambatnya pelayanan pengoperasian keagenan kapal asing. Faktor penyebab atau kendala yang menghambat pelayanan pengoperasian keagenan kapal asing yang disebabkan oleh adanya keterbatasan kapal tunda dalam pelayanan di pelabuhan Gresik. Di setiap pelabuhan harus mempunyai fasilitas yang menunjang guna memenuhi kebutuhan di lapangan, apabila terdapat keterbatasan kapal tunda maka aktivitas kapal pun menjadi terganggu dan akan berdampak kurang optimal. Hal ini disampaikan oleh staf lapangan Pelindo III Gresik, "Saat ini memang jumlah kapal tunda yang dimiliki di pelabuhan Gresik masih sangat terbatas, sehingga aktivitas pergerakan kapal menjadi terhambat. Dengan fasilitas saat ini maka belum bisa mencukupi kebutuhan di lapangan." Faktor kedua yang menghambat dalam pelayanan kapal kapal asing adalah adanya sistem pengurusan dokumen di Instansi Pemerintah Bea Cukai yang belum menerapkan sistem online 24 (dua puluh empat) jam.

Dalam hal ini keagenan mempunyai permasalahan mengenai sistem pelayanan yang berlangsung di Instansi Bea Cukai, karena di dalam keagenan pelayanan dilakukan dengan sistem 24 (dua puluh empat) jam maka setiap saat keagenan harus siap memberikan pelayanan kepada kapal asing, karena setiap kapal asing yang akan berlayar dari pelabuhan Gresik keagenan harus mengurus dokumen manifest outward dan dalam pengurusan manifest tersebut keagenan kapal asing dihadapkan dengan waktu pelayanan Bea Cukai yang terbatas.
Hal ini disampaikan oleh seksi administrasi manifest Bea Cukai Gresik, "Bea Cukai sudah melakukan pemanfaatan teknologi dalam sistem pelayanan jasa, saat ini Bea Cukai sudah menggunakan sistem EDI (electronic data interchange) sesuai anjuran pemerintah. Tapi untuk saat ini pengurusan clearance kapal asing belum bisa menggunakan sistem online karena belum ada ketetapan dari pemerintah maka perusahaan keagenan atau pengguna jasa harus datang ke kantor Bea Cukai untuk pengajuan manifest."

Dari hasil dokumentasi diperoleh laporan data kedatangan kapal asing di Gresik yang telah ditangani oleh 3 (tiga) perusahaan keagenan pelayaran di Pelabuhan Gresik antara lain, PT. Varia Usaha Lintas Segara, PT. Bintang Samudra Utama, dan PT. Bahtera Adhiguna yang bergerak di bidang keagenan, yaitu:

Tabel 1. Kedatangan kapal asing PT. Varia Usaha Lintas Segara

\begin{tabular}{clc}
\hline No & \multicolumn{1}{c}{ Bulan } & Jumlah Kapal Asing \\
\hline 1 & Agustus 2014 & 3 kapal asing \\
2 & September 2014 & 2 kapal asing \\
3 & Oktober 2014 & 2 kapal asing \\
4 & November 2014 & 3 kapal asing \\
5 & Desember 2014 & 2 kapal asing \\
6 & Januari 2015 & 4 kapal asing \\
7 & Februari 2015 & 2 kapal asing \\
8 & Maret 2015 & 2 kapal asing \\
9 & April 2015 & 3 kapal asing \\
10 & Mei 2015 & 3 kapal asing \\
11 & Juni 2015 & 2 kapal asing \\
\hline \multicolumn{2}{c}{ Total } & 28 kapal asing \\
\hline
\end{tabular}

Tabel 2. Kedatangan kapal asing PT. Bintang Samudra Utama

\begin{tabular}{ccc}
\hline No & Bulan & Jumlah Kapal Asing \\
\hline 1 & Agustus 2014 & 7 kapal asing \\
2 & September 2014 & 13 kapal asing \\
3 & Oktober 2014 & 16 kapal asing \\
4 & November 2014 & 6 kapal asing \\
5 & Desember 2014 & 10 kapal asing \\
6 & Januari 2015 & 9 kapal asing \\
7 & Februari 2015 & 8 kapal asing \\
8 & Maret 2015 & 7 kapal asing \\
\hline
\end{tabular}




\begin{tabular}{ccc}
\hline No & Bulan & Jumlah Kapal Asing \\
\hline 9 & April 2015 & 4 kapal asing \\
10 & Mei 2015 & 4 kapal asing \\
11 & Juni 2015 & 7 kapal asing \\
\hline & Total & 91 kapal asing \\
\hline
\end{tabular}

Tabel 3. Kedatangan kapal asing PT. Bahtera Adhiguna

\begin{tabular}{clc}
\hline No & \multicolumn{1}{c}{ Bulan } & Jumlah Kapal Asing \\
\hline 1 & Agustus 2014 & 4 kapal asing \\
2 & September 2014 & 4 kapal asing \\
3 & Oktober 2014 & 6 kapal asing \\
4 & November 2014 & 4 kapal asing \\
5 & Desember 2014 & 4 kapal asing \\
6 & Januari 2015 & 8 kapal asing \\
7 & Februari 2015 & 4 kapal asing \\
8 & Maret 2015 & 5 kapal asing \\
9 & April 2015 & 2 kapal asing \\
10 & Mei 2015 & 5 kapal asing \\
11 & Juni 2015 & 3 kapal asing \\
\hline & Total & 49 kapal asing \\
\hline
\end{tabular}

Pengurusan proses pelayanan di Karantina yaitu pihak keagenan kapal dari pengurusan dokumen clearance in membutuhkan waktu 20 (dua puluh) menit dan pengurusan dokumen clearance out membutuhkan waktu 10 (sepuluh) menit, sehingga tidak terdapat kendala dalam pengurusan di Instansi Karantina.

Pengurusan proses pelayanan di Bea Cukai yaitu Rencana Kedatangan Sarana Pengangkut (RKSP) membutuhkan waktu 30 (tiga puluh) menit, berikutnya proses clearance in yang membutuhkan waktu 45 (empat puluh lima) menit, dan proses clearance out membutuhkan waktu 45 (empat puluh lima) menit, dari 3 (tiga) proses pengurusan tersebut pihak keagenan mendapatkan kendala pada proses clearance out karena pada proses ini keagenan tidak bisa setiap saat melakukan clearance out, dengan terkendala pada jam kerja di Bea Cukai, sedangkan kapal lepas bisa terjadi siang dan malam hari disamping faktor di atas terdapat kendala yang dialami oleh keagenan pada pengurusan keberangkatan kapal yang masih menggunakan sistem manual, sehingga membutuhkan waktu lama dan birokrasi yang panjang sehingga pengurusan pelayanan kapal asing menjadi terkendala.

\section{Pengurusan proses pelayanan di} Imigrasi yaitu keagenan kapal asing membutuhkan waktu 15 (lima belas) menit untuk clearance in dan 10 (sepuluh) menit untuk clearance out, dalam hal ini pihak pengguna jasa maupun pihak keagenan tidak mendapatkan hambatan dan kendala.

Dari pengurusan kapal asing di Instansi Syahbandar pada saat pengurusan sebelum kapal tiba PKKA membutuhkan waktu 15 (lima belas) menit, pada saat clearance in membutuhkan waktu 90 (sembilan puluh) menit, dan pada saat clearance out membutuhkan waktu 60 (enam puluh) menit. Dalam pengurusan ini pihak pengguna jasa tidak menemukan kendala karena dalam pengurusan di Syahbandar menggunakan sistem satu pintu sehingga dapat mempermudah pengguna jasa dan pihak keagenan.

Pengurusan proses pelayanan di Instansi Pelindo III Gresik, pengguna jasa atau pihak keagenan membutuhkan waktu 15 (lima belas) menit untuk clearance in, dan 15 (lima belas) menit untuk clearance out, tetapi dalam aktivitas di lapangan dalam proses kapal sandar dan lepas keagenan mempunyai hambatan yaitu kurangnya kapal tunda. Waktu normal yang dibutuhkan untuk menunggu kapal tunda yaitu 1 (satu) jam dikarenakan antrian kapal tunda yang banyak sehingga waktu tunggu kapal tunda menjadi 3 (tiga) jam, hal ini menjadi tidak efektif.

Dapat disimpulkan bahwa berdasarkan data di atas dari pengumpulan data observasi, wawancara, dan dokumentasi bahwa hambatan dan kendala di atas memang terjadi dalam proses pelayanan pengoperasian kapal asing di Gresik. Bagaimana upaya-upaya yang dilakukan dalam meningkatkan pelayanan pengoperasian keagenan kapal asing di Gresik?

Dalam usaha untuk mengatasi permasalahan yang dihadapi sewaktu penanganan kapal asing, keagenan harus mengambil tindakan yang tepat. Hal ini dilakukan agar kegiatan pelayanan operasional keagenan kapal asing menjadi lebih lancar dan agar tidak menjadi masalahmasalah yang berarti yang biasanya timbul di lapangan. 
Pada persaingan keagenan di Gresik sangat ketat dan pihak-pihak yang berkaitan dengan sarana dan prasarana harus dapat mendukung serta sistem pelayanan yang lebih cepat dan optimal. Upaya yang dilakukan berdasarkan data di atas pihak PELINDO dan Bea Cukai telah mengimplementasikan, yaitu upaya yang dilakukan pihak PELINDO dalam meminimalisir waktu tunggu kapal tunda karena kapal tunda di Pelabuhan Gresik yang terbatas yaitu meminta bantuan kapal tunda dari Pelabuhan Surabaya sebanyak 2 (dua) sampai 3 (tiga) kapal tunda, tergantung kepadatan aktivitas olah gerak kapal di Pelabuhan Gresik.

Dari proses tunggu kapal tunda yang memakan waktu 3 (tiga) jam menjadi 1 (satu) jam. Maka waktu pengiriman barang lebih cepat, dan kelancaran alur pelayaran menjadi efektif dan efisien. Sehingga tercipta pelayanan keagenan kapal asing dalam menunjang kelancaran kegiatan operasional. Upaya yang dilakukan Instansi Bea Cukai yaitu dalam pengurusan clearance di luar jam kerja, pihak keagenan atau pengguna jasa dapat melakukan konfirmasi waktu pengajuan kepada petugas. Sehingga pelayanan tetap dilakukan walaupun di luar jam kerja dan berdampak kepada kelancaran kapal dalam melakukan aktivitas.

\section{KESIMPULAN}

Bedasarkan penelitian yang telah dilakukan di Pelabuhan Gresik, perusahaan keagenan, dan instansi terkait maka dapat disimpulkan bahwa pelayanan pengoperasian keagenan kapal asing di Gresik mengalami beberapa kendala dan hambatan antara lain yaitu fasilitas pelayanan kapal tunda di Pelabuhan Gresik yang kurang memadai dan sistem pengurusan clearance dokumen di Instansi Bea Cukai yang belum menerapkan sistem online 24 (dua puluh empat) jam sehingga membutuhkan birokrasi yang panjang dan waktu yang lama. Kendala dan ketidakoptimalnya pelayanan tersebut disebabkan 2 (dua) hal, faktor pertama adalah kurangnya fasilitas kapal tunda yang ada di pelabuhan Gresik, terbatasnya fasilitas ini mengakibatkan hambatan kapal tidak bisa cepat sandar atau lepas dari dermaga karena harus menunggu antrian kapal tunda dan mengakibatkan pengurusan kapal asing menjadi terkendala. Faktor kedua dikarenakan proses penyelesaian dokumen atau clearance di Bea Cukai yang belum menggunakan sistem teknologi modern yaitu dengan sistem online 24 (dua puluh empat) jam. Sehingga pada saat pengurusan diluar jam kerja pengguna jasa tidak bisa sewaktuwaktu mengajukan proses clearance baik clearance in atau clearance out, karena jam kerja yang terbatas serta pengurusan birokrasi yang panjang.

\section{DAFTAR PUSTAKA}

Azwar, Saiffudin. 2007. Sikap Manusia Teori dan Pengukurannya. Yogyakarta: Pustaka Pelajar

Burhanuddin, S. 2013. Prosedur Hukum Pengurusan Bea dan Cukai. Yogyakarta: Pustaka Yustisia

Moleong, Lexy J. 2015. Metodologi Penelitian Kualitatif. Bandung: PT. Remaja Rosdakarya

Peraturan Menteri Perhubungan Republik Indonesia No. 57 Tahun 2015 Tentang Penundaan Kapal.

Santoso, Budi. 2015. Keagenan (agency). Bogor: Ghalia Indonesia

Suyono, R. P. 2007. Shipping Pengangkut Intermoda Ekspor Impor Melalui Laut. Jakarta: PPM

Sugiyono. 2012. Metode Penelitian Pendidikan. Bandung: Alfabeta

Widoyoko, Eko Putro. 2012. Teknik Penyusunan Instrumen Penelitian. Yogyakarta: Pustaka Pelajar

Undang-Undang Pelayaran RI No. 17 Tahun 2008. Jakarta: Sinar Grafika

Undang-Undang Republik Indonesia No. 39 Tahun 2007 Tentang Cukai

kbbi.web.id, Kamus Besar Bahasa Indonesia Online. 
Jurnal Dinamika Bahari Vol. 7 No. 2 Edisi Mei 2017

www.bahteradhiguna.co.id

www.bintang-samudra.co.id

www.variausaha.com 